\title{
INFESTASI CAPLAK (Boophilus microplus) PADA TERNAK SAPI DI DESA PINABETENGAN KECAMATAN TOMPASO KABUPATEN MINAHASA
}

\author{
Jordan Ch. Konore, Agustinus Lomboan, Endang Pudjihastuti, \\ Srimalasinha Sane, Meis Nangoy* \\ Fakultas Peternakan Universitas Sam Ratulangi Manado
}

\begin{abstract}
ABSTRAK
Penelitian infestasi caplak (Boophilus microplus) pada ternak sapi telah dilaksanakan di desa Pinabetengan untuk mengestimasi prevalensi dan preferensi infestasi caplak pada ternak sapi di Desa Pinabetengan, Kecamatan Tompaso, Kabupaten Minahasa. Penelitian ini menggunakan metode purposive random sampling. Sejumlah 64 ekor sapi digunakan dalam penelitian ini. Caplak dikoleksi mulai dari kepala/telinga, leher, punggung, pangkal paha, kaki, dan ekor, selanjutnya dimasukkan ke dalam botol berisi alkohol $70 \%$ berdasarkan bagian tubuh ternak. Berdasarkan hasil penelitian diperoleh 30 ternak sapi terinfestasi caplak. Preferensi infestasi caplak pada bagian tubuh ternak sapi secara berurut sebagai berikut bagian kepala, telinga, leher, punggung, pangkal paha, kaki,ekor adalah paling banyak terinfestasi caplak. Preferensi infestasi caplak berdasarkan jenis kelamin, ternyata bahwa ternak sapi betina lebih sering terinfestasi caplak. Berdasarkan hasil dan pembahasan dapat disimpulkan bahwa Ternak sapi di desa Pinabetengan
\end{abstract}

*Kosepondensi (corresponding author)

Email: mjnangoy@yahoo.com
Utara yang terinfestasi caplak Boophilus microplus sebesar 46,9\%. Preferensi infestasi caplak pada bagian tubuh yang paling banyak ditemukan pada bagian pangkal paha ternak sapi. Preferensi infestasi caplak pada ternak sapi betina sebanyak 4,38 ekor caplak, sedangkan ternak jantan 3,33 ekor caplak.

Kata kunci : Caplak, Infestasi, Preferensi, Prevalensi, Sapi

\section{ABSTRACT}

This research was conducted in Pinabetengan village to calculate the prevalence and preference of tick infestations in cattle in Pinabetengan Village, Tompaso District, Minahasa Regency. This study uses the Purposive Random Sampling method. 64 cattles were used as samples. Collecting ticks starts from the head, neck, back, groin, legs, and tail, then put in a bottle containing $70 \%$ alcohol based on the body parts of the animal. Based on the result research that 30 cattles were found to be infested of tick. Preferences of ticks on body parts of cattle show that at the groin is the most infestation of ticks. The tick infestation preference based on sex it turn out that female cattle are more often infested with tick. Based on the results and 
discussion it can be concluded that the cattle in the North Pinabetengan village infested with Boophilus microplus tick is $46.9 \%$. Preference for tick infestation on the body parts that are most commonly found in the groin of cattle. Preference for tick infestation in female cattle is 4.38 ticks, while male cattle are 3.33 ticks.

Keywords: Ticks, Infestations, Preference, Prevalence, Cow

\section{PENDAHULUAN}

Ternak sapi merupakan salah satu ternak yang mempunyai nilai jual tinggi, karena unggul menghasilkan daging, susu dan kulit. Peternakan sapi memiliki potensi yang dapat dikembangkan sebagai salah satu usaha yang sangat menguntungkan, namun usaha peternakan memerlukan modal yang besar, terutama untuk pengadaan pakan dan bibit. Modal yang besar sulit dipenuhi oleh peternak di Indonesia sehingga peternakan sapi di Indonesia didominasi oleh peternak rakyat berskala kecil (Hadi dan Ilham, 2002).

Sulawesi Utara adalah daerah yang memiliki potensi yang besar untuk pengembangan usaha ternak sapi karena memiliki sumber daya alam yang mendukung ketersediaan pakan seperti lahan penggembalaan di bawah pohon kelapa dan sawah. Akan tetapi di Desa Pinabetengan, sistem pemeliharaan ternak sapi pada umumnya dilakukan secara tradisional dengan tujuan pemeliharaannya sebagai usaha sambilan, sehingga produktivitasnya terbilang rendah karena pengelolaan yang sifatnya masih tradisional dan kurang memperhatikan kondisi peternakan sapi sehingga kondisi ternak sapi di desa Pinabetengan terlihat kurus meskipun bahan pakan untuk ternak sapi itu sendiri masih bisa terpenuhi sehinggah diduga ternak sapi di desa Pinabetengan terserang berbagai jenis penyakit yang dapat disebabkan oleh beberapa faktor, salah satunya ektoparasit. Ektoparasit adalah parasit yang hidup dan berkembang biak pada inangnya (ternak yang lebih besar). Beberapa ektoparasit yang sangat merugikan usaha peternakan sapi antara lain caplak, kutu, lalat, dan tungau (Harun, 2015). Oleh karena itu telah dilakukan penelitian infestasi caplak (Boophilus microplus) pada ternak sapi di desa Pinabetengan untuk mengestimasi prevalensi dan preferensi infestasi caplak pada ternak sapi. 


\section{MATERI DAN METODE PENELITIAN}

Penelitian ini menggunakan metode Purposive Random Sampling yaitu penentuan titik pengambilan sampel dilakukan pada lokasi yang terpilih berdasarkan hasil survey. Sejumlah 64 ekor 389ernak sapi digunakan sebagai sampel dalam penelitian ini. Pengambilan caplak mulai dari kepala, leher, punggung, pangkal paha, kaki, dan ekor, selanjutnya dimasukkan ke dalam botol berisi alkohol $70 \%$ berdasarkan bagian tubuh ternak. Selanjutnya sampel caplak dibawa ke Laboratorium Fakultas Peternakan untuk dilakukan identifikasi menurut Hopla et al. (1994). Penelitian ini dilakukan selama 2 bulan mulai dari Agustus sampai dengan Oktober 2018 . Lokasi penelitian di desa Pinabetengan Kecamatan Tompaso Kabupaten Minahasa Sulawesi Utara. Penelitian ini yaitu untuk menghitung prevalensi dan preferensi infestasi caplak pada ternak sapi di Desa Pinabetengan, Kecamatan Tompaso, Kabupaten Minahasa dengan menggunakan rumus prevalensi infestasi caplak
Prevalensi=

$\frac{\text { jumlah sapi yang terinfestasi }}{\text { jumlah sapi yang diamati }} X 100$

\section{HASIL PEMBAHASAN}

\section{Prevalensi Infestasi Caplak (Boophilus microplus)}

Berdasarkan hasil penelitian ternyata bahwa jumlah ternak sapi yang terinfeksi caplak di desa Pinabetengan sebesar $46,9 \%$.

Hasil yang diperoleh ini adalah lebih kecil apabila dibandingkan dengan hasil penelitian dari Patodo et al. (2018) yaitu sebesar $100 \%$ hal ini dikarenakan didesa Pinabetengan ada beberapa peternak yang telah menyadari dan mengetahui akibat dari serangan caplak yang dapat merugikan para peternak. Hasil penelitian yang diperoleh di desa Pinabetengan ini lebih tinggi jika dibandingkan dengan hasil penelitian yang dilakukan oleh Manurung (2002), seperti di Kecamatan Ciracap, Jawa Barat yakni ternak sapi yang terinfestasi caplak sebesar $44 \%$, yaitu sebanyak 82 ekor yang terinfestasi dari 187 ekor sapi. Sedangkan di Kecamatan Surade, Jawa Barat, ternak sapi yang terinfestasi caplak sebesar 30\%, 
dengan jumlah ternak sapi 32 ekor yang terinfestasi dari 107 ekor sapi, hasil ini menunjukan bahwa di Indonesia caplak telah menjadi masalah tersendiri bagi para peternak sapi, terutama di beberapa daerah seperti Sulawesi Utara, Jawa Barat, dan berbagai daerah lainnya (Sigit et al.,1983).

Menurut Little (2008), Indonesia merupakan salah satu daerah yang mempunyai kelembaban yang tinggi dan kurangnya sinar matahari sehingga menjadi faktor pendukung bagi berbagai jenis ektoparasit. Bila suhu lingkungan memungkinkan dengan suhu $20-31^{\circ} \mathrm{C}$ dan memiliki kelembaban 70-90\%, maka telur akan menetas menjadi larva kemudian naik ke tubuh ternak sapi untuk berkembang biak menjadi nimfa sampai dewasa (Hitchcock, 1955).

\section{Preferensi Infestasi Caplak Pada Bagian Tubuh (ekor caplak/ekor sapi)}

Hasil penelitian di desa Pinabetengan mengenai preferensi infestasi caplak pada tubuh ternak sapi, seperti terlihat pada Gambar 1.

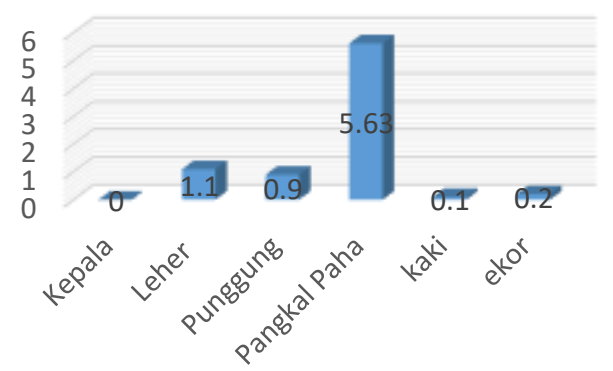

Gambar 1. Rata-Rata Preferensi Infestasi Caplak (ekor caplak/ekor sapi) Berdasarkan Bagian Tubuh Ternak Sapi

Hasil penelitian yang diperoleh di desa Pinabetengan (Gambar 1) mengenai preferensi infestasi caplak pada beberapa bagian-bagian tubuh ternak sapi menunjukkan bahwa pada bagian kepala tidak terinfestasi caplak, sedangkan pada bagian pangkal paha adalah paling banyak terinfestasi caplak yaitu sebesar 5,63 ekor dibandingkan dengan bagian tubuh yang lain seperti leher, punggung, kaki dan ekor. Pada bagian pangkal paha merupakan tempat yang disenangi caplak sebagai tempat untuk berlindung. Sedangkan bagian kepala jarang ditemukan caplak sebab bagian tersebut merupakan daerah yang terbuka dan memudahkan para peternak untuk membersihkan caplak dari ternak sapi. Produksi telur caplak juga sangat ditentukan oleh banyaknya darah yang 
dihisap, semakin banyak darah yang dihisap caplak maka semakin tinggi produksi telurnya. Darah yang dihisap oleh caplak mengandung protein yang berfungsi sebagai pembentukan telur. Caplak tidak menghisap darah begitu saja dari semua ternak, tetapi juga caplak dapat mempertimbangkan kepekatan kompenen darah, seperti eritrosit dan plasma protein inangnya (Willadsen et al., 1984).

\section{Preferensi Infestasi Berdasarkan Jenis Kelamin Ternak Sapi}

Pada Gambar 2 dapat dilihat ratarata preferensi infestasi berdasarkan jenis kelamin. Jumlah ternak yang paling banyak terinfestasi caplak yaitu ternak sapi betina sejumlah 4.38 ekor caplak/ekor sapi, sedangkan ternak jantan 3.33 ekor caplak/ekor sapi.

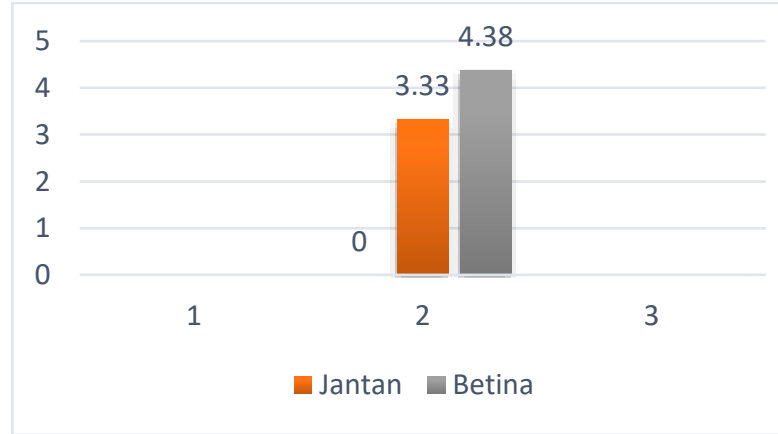

Gambar 2. Rata-Rata Preferensi Infestasi Caplak Berdasarkan Jenis Kelamin Ternak Sapi.
Hasil penelitian menunjukan bahwa ternak sapi betina lebih banyak terinfestasi caplak karena pada umumnya para peternak sapi kurang memperhatikan kesehatan ternak betina dan hanya dijadikan sebagai ternak pekerja, sedangkan ternak jantan pada umumnya dijadikan ternak pedaging karena sapi jantan akan mempunyai pertumbuhan yang lebih cepat dari pada sapi betina karena adanya hormon androgen (Bures dan Barton, 2012). Sementara yang paling sering memperoleh perawatan kesehatan dengan cara penyuntikan obat ektoparasit yaitu pada ternak jantan, sedangkan pada ternak betina kurang. Disamping itu sapi betina dapat pula dijadikan tenaga kerja penarik bajak karena sifatnya yang lebih tenang dan mudah dikendalikan dibandingkan sapi jantan, oleh sebab itu ternak betina kurang mengalami perawatan secara teratur karena sering dijadikan sebagai ternak pekerja (Fatah $e t$ al., 2012).

Sedangkan menurut hasil penelitian dari Patodo et al. (2018) Sapi betina di desa Tolok kecamatan Tompaso kabupaten Minahasa lebih tinggi terinfestasi caplak dengan rata-rata 32,05 ekor caplak, sedangkan sapi jantan 
memperoleh 20,65 ekor caplak. Karena adanya faktor stres yang dialami oleh ternak sapi betina.

\section{KESIMPULAN}

Berdasarkan hasil dan pembahasan dapat disimpulkan bahwa Ternak sapi di desa Pinabetengan yang terinfestasi caplak Boophilus microplus sebesar 46,9\%, preferensi infestasi caplak pada bagian tubuh yang paling banyak ditemukan pada bagian pangkal paha ternak sapi. Dan preferensi infestasi caplak pada ternak sapi betina sebesar 4,38 ekor caplak/ekor sapi, sedangkan ternak jantan 3,33 ekor caplak/ekor sapi

\section{DAFTAR PUSTAKA}

Bures and L. Barton, 2012. Growrt performance, carcass traits and meat quality of bulls and heifers slaughtered at different ages. Czech J. Anim. Sci. 57: 34-43

Fatah, Wiyatna., E. Gurnadi, dan K. Mudikdjo. 2012. Produktivitas sapi Peranakan Ongole pada peternakan rakyat di Kabupaten Sumedang. Jurnal Ilmu Ternak Universitas Padjadjaran 12(2) : 59-68.
Hadi, P.U. dan N. Ilham. 2002. Problem dan prospek pengembangan usaha pembibitan sapi potong di Indonesia. Jurnal Penelitian dan Pengembangan Pertanian 21(4): 148-157.

Harun, D. 2015. Sistem Pakar Identifikasi Ektoparasit Yang Menyebabkan Penyakit Pada Sapi. Skripsi Jurusan Teknik Informatika Universitas Negeri Gorontalo.

Hitchcock, L.F. 1955. Studies on the parasite stage of the cattle tick. Boophilus microplus (Canestrin) (Acarina, Ixodidae) Aust. J. Zool. 3: 145-155.

Hopla, C.E., L.A.Duren dan J.E Keirans. 1994. Ectoparasites and classification. Rev. Science Technology Off. Int. Epiz. 13(4): 986-1017.

Little, D. A. 1963. The effect of cattle tick infestation on the growth rate of cattle. Australian Veterinary Journal. 39(1):6-10

Manurung, J. 2002. Studi prevalensi infestasi caplak pada sapi di Kecamatan Ciracap dan Kecamatan Surade Kabupaten Sukabumi Jawa Barat serta caracara peternak menanggulanginya. Prosiding. Seminar Nasional Terknologi Peternakan dan Veteriner. Hal 65-73. 
Patodo, G., M.J. Nangoy, G.J.V Assa, dan A. Lomboan 2018. Infestasi Caplak Pada Sapi Di Desa Tolok Kecamatan Tompaso Kabupaten Minahasa. Zootec 38(2): 306-313.

Sigit, H. Singgih, Soetiyono Partosoedjono dan M. Saleh Akib. 1983. Laporan Penelitian: Inventarisasi Dan Pemetaan Parasit Indonesia Tahap Pertama. Ektoparasit. Proyek Peningkatan Dan Pengembangan Perguruan Tinggi IPB.

Willadsen, P., D.H. Kemp, dan R.V. Mckenna. 1984. Bloodmeal ingestion and utilization as component of host specificity in the tick, Boophilus microplus. Zeitschrift für Parasitenkunde 70(3): 415-420. (Ringkasan dalam: Rev. Appl. Entomol. Seri B 73(1) : 175 ; 1985) . 